\title{
Utilization of Edmodo as an Online Tool in EFL Writing Class to Increase Students' Writing Ability
}

\author{
M. Zaini Miftah \\ English Education Department, Faculty of Teacher Training and \\ Education, \\ IAIN Palangka Raya \\ miftahmzaini@gmail.com \\ DOI: http://dx.doi.org/10.18326/rgt.v11i1.37-58
}

Submission
Track:
Received:
09-11-2017
Final Revision:
30-05--2018
Available online:
01-06-2018

Corresponding Author: M. Zaini Miftah miftahmzaini@gmail.com

\begin{abstract}
This article reports the results of investigation on the utilization of Edmodo as an online tool in EFL writing class to increase the students' ability in producing an argumentative essay. Classroom Action Research was applied in the study. 15 Indonesian EFL students who enrolled in the course of Argumentative Writing became the participants of the study. Observation, writing task, questionnaire, and field notes were used for the data collection. The data obtained were categorized into qualitative and quantitative data. The collected data were then analyzed for the conclusion drawn. The results show that the utilization of Edmodo in EFL writing class could significantly increase the students' ability in producing an argumentative essay in the Cycle 2. The Appropriate teaching procedures are; prepare the teaching materials, introduce Edmodo, guide students to get ready to use Edmodo, give an opportunity to students to get in the Edmodo group, train students to use Edmodo group, group students in the small group via Edmodo, give students writing tasks through
\end{abstract}


Edmodo, provide a guideline and tell students to follow the guideline to access their small group, ask students to post their first drafts of an argumentative essay on their small groups, ask students to give feedback on their peers' works, ask students to revise their drafts of the argumentative essay based on the their peers' feedback and teacher, and ask students to post their final products of an argumentative essay on their Edmodo account.

Keywords: Edmodo, online tool, EFL writing class, writing ability, argumentative essay

\section{INTRODUCTION}

The study addresses the question of how Edmodo as an online tool in writing class of English as a foreign language (EFL) can improve students' ability in writing an argumentative essay. The researcher expects to contribute to knowledge theoretically and practically. Theoretically, it was expected to support the theory of the use of Edmodo in the teaching of writing specifically in the development of utilization of Edmodo in the writing teaching of EFL. Meanwhile, practically, teachers can get benefits from Edmodo as an online tool or e-learning community that could be as one of the alternative ways in EFL writing class. Also, the students could be engaged in writing activities collaboratively in order that their writing ability improves.

In the teaching and learning of English as a foreign language, information and communication technology (ICT) is widely used. ICT has become an important aspect of life and its various types have been established in different parts of life such as in education field (Cahyono, 2010). Also, the technology use of computer and internet being developed in 
this digital era gives big influence on higher education (Çobanoğlu, 2018), and the trend current technology now is shifted from the traditional way with face-to-face to the online community of practices (Trust, 2015). Thus, the communication technology uses such as the utilization of Edmodo that is implemented via internet can be used for teaching English, more specifically for teaching writing.

On the internet, both teachers and students can browse learning materials and access virtual learning environments and resources for free (Kodriyah, 2016). Teachers can bring students to another way of learning, i.e. e-learning, because they can access the internet every time and everywhere as their information sources (Kistow, 2011). In short, by utilizing technology in English classes, it could assist teachers and students for the easier and more motivated teaching and learning process.

One of the online tools or the educational social networking sites is Edmodo (Anbe, 2013). Jeff O'Hara and Nick Borg has designed and developed it and make it available at www.edmodo.com since 2008 (Kongchan, 2013). It is free, private and secure learning network, which is similar to Facebook (Jarc (2010) in Kongchan, 2013). Edmodo is useful for both teachers and students. It provides simple functions or features for teachers in creating and managing their online classroom environment. Moreover, it assists students to contact and work easily with their online classmates and teachers. This social networking device provides a secure community for the connection, collaboration and learning among teachers and students (Trust, 2017). Edmodo offers privacy to both teachers and their students. It is only the teacher of the classroom, who can create and manage the Edmodo accounts. The access to the Edmodo Class is limited only to 
students who receive a group code from the teachers and register in the group. Students from other classes cannot participate and join in the group (Kongchan, 2013). In short, the teacher of the Edmodo English class can invite students to get collaboratively involved in the learning process of the virtual classroom community of the writing. For the collaboration process, it is as suggested by Alwasilah (2006) as cited in Supiani (2012), to develop confidence, authorship, and enjoyment of being parts in the community of writing, writing collaboratively should be applied in the writing class.

Since the Edmodo utilization makes the use of the power of online social media in the atmosphere of education (Ursavaş \& Reisoglu, (2017) such as in the Edmodo classroom activities, teachers can send text alerts, messages attached with a file or a link, reply students' messages, send out quizzes and assignments, receive completed assignments, give feedback, assign polls, maintain a class calendar, and contact the whole class, small groups, or even individual students. Meanwhile, students can send a message attached with a file and a link, store and share content, e.g. a file or a link, submit homework, assignments, and quizzes, receive and reply their teacher's feedback, messages, alerts, vote on polls as well as set their own calendar. Students can communicate with their teachers, the whole class, and their small group. The only limitation is that they cannot communicate with individual students via Edmodo (Kongchan, 2013).

With regard to Edmodo used in teaching English as first, second or foreign language, some researchers have conducted studies on the use of Edmodo in writing classes. Holland and Muilenburg (2011) studied the students participating in literature discussions using asynchronous discussion platform found on Edmodo.com. It was to improve the quality and the depth of student discussion of literature in (and potentially outside of) an English 
classroom. The results showed that Edmodo successfully expanded the students' ability to ask insightful questions and elicit meaningful responses with minimal intervention from the teacher because they gained more experience in the literature-based online discussion.

Ali (2015) carried out the study aiming at investigating the students' voices towards Edmodo use to supplement face-to-face way in the English language class. It reported that the significant implications of the study in English language teaching applied by the teacher needs knowledge of using tools such as Edmodo as teaching and learning platform. Purnawarman et al. (2016) did their research observing Edmodo as a learning platform in a blended learning setting combined with genre-based approach. The results informed that it was possible to integrate Edmodo into genre-based approach writing cycles within the writing class. Kodriyah (2016) investigated the effectiveness of the use of Edmodo based on the students' perception. The results indicated that the majority of the students considered Edmodo as an effective tool to support their English learning even though they got problem with internet access.

Salasiah (2016) explored students' perception or students' voice on online learning particularly Edmodo application in the class of writing course. The research indicated that using digital learning especially Edmodo in the class of writing could significantly contribute to positive change in the process of learning such as improving students' digital learning knowledge. Students can access various materials of learning writing online that enrich their horizon. The previous research focused on investigating students' view on Edmodo application in the writing class, but the current research more 
focuses on investigating how Edmodo can be implemented for the student's writing ability improvement.

In addition, Al-Naibi, Al-Jabri, and Al-Kalbani (2018) did a classroom action research in EFL classroom at Arab university. It was found that by using Edmodo integrating in the writing class, the students' writing had significant improvement. In the present study, it uses classroom action research design in different atmosphere of Indonesian EFL writing class with focus on the use of Edmodo to improve students' writing performance in argumentative essay writing.

At the English Department of State Islamic Institute (IAIN) Palangka Raya, Indonesia, in which English is taught as a foreign language (EFL). The use of technology to teach writing tends to be challenging and only some teachers facilitate their classrooms with it. In the current study, the teacherresearcher tried to implement the use of technology such as Edmodo in his EFL writing class.

\section{RESEARCH METHODS}

\section{Type of research, data collection, and data analysis}

The research design applied in this study was classroom action research (CAR). It covers four steps - planning, implementing, observing, and reflecting (Kemmis \& McTaggart, 1992, p. 11-13). These phases took place in 2 cycles with 4 meetings each. The participants were 15 Indonesian fourth-year undergraduate EFL students, who enrolled in an Argumentative Writing course, particularly in English Education Department of State Islamic Institute (IAIN) Palangka Raya, Central Kalimantan, Indonesia. Dealing with data collection, Koshy (2006, p. 85) asserts that an action research can apply a variety of methods to collect the data. The instruments 
required in this study were writing tasks, observation checklist, field notes, and questionnaire. The students' works were analyzed at the end of the cycle by utilizing an analytic scoring rubric for argumentative essay adapted from Oshima \& Houge (2007, p. 316).

\section{Research procedures}

The preliminary study was conducted in the first week of the meeting of the course. It obtained the data through the writing test and observation. The study found that the students had been interested in learning writing and had unsatisfactory abilities in writing an argumentative essay. This happened since there was no interesting tools or ways of teaching and learning strategy to engage them in the collaborative activities in writing class.

\section{Planning}

In this phase, the teacher developed the instructional procedures of Edmodo as an online tool in writing activities in the EFL writing class. In applying Edmodo in teaching writing, the researcher modified the instructional procedures proposed by Stroud (2010) and Purnawarman et al. (2016). The modification was based on the material provided in the course of argumentative writing and the students' need. When implementing instructional procedure for utilizing Edmodo in teaching writing, the process of writing was applied, i.e. prewriting, drafting, revising, editing and publishing (Miftah, 2015). In addition, the process of writing implemented the techniques of peer and teacher feedback so that the students could engage in the writing activities via Edmodo as a virtual writing community. By engaging them in the writing activities the students can hopefully get involved in giving feedback on their peers' work in order to produce better writings. 
In preparing the classes, lesson plan was developed based on the course syllabus of argumentative writing curriculum of the university. It focused on the implementation of Edmodo in the writing class.

To know the students' writing ability and see the progress of their writing ability, the students produced argumentative essay through the writing activities via Edmodo. They followed the procedures of prewriting activities, writing first drafts, giving feedback on peers' argumentative essay focused on introductory, body, and concluding paragraphs, revising and editing the drafts, and publishing the final product in each cycle.

In Cycle I, the students were assigned to produce argumentative essay based on the topics of their interest. Meanwhile, in Cycle II, the students wrote their argumentative essay based on the topics provided by the teacher. They chose one of five topics expressing agreement or disagreement toward the given themes. Topic 1 was "the future status of English teacher is assured". Topic 2 discussed about "the death sentence for corruptors to establish good governance in Indonesia". Topic 3 dealt with "the urbanization rate should be minimized for the safety of Palangka Raya city". Topic 4 focused on "people should apply diet program should for their good health". Topic 5 addressed the problem of "the English students of IAIN Palangka Raya should go abroad for their better future".

At the end of each cycle, the students collected portfolio of their final works. The teacher, then, analyzed the students' works using analytic scoring rubric for argumentative essay (Oshima \& Houge, 2007, p. 316). The data obtained from this instrument were in the form of scores.

The criteria of success were set up in advance as a basis to determine whether the action conducted was successful or not. This study is said to be successful if it meets two criteria of success: (1) the students' writing 
achievement enhances, and (2) the students are actively involved in the writing activities.

\section{Implementing}

In this phase, Cycle I applied the instructional procedures of implementing Edmodo in the writing class through the activities of training on how to use Edmodo in writing class (in-class and online activities). Task 1 was doing prewriting activities in Edmodo (in class and online activities). Task 2 was writing first draft. Task 3 was giving feedback on peer's argumentative essay (Focus on Introductory Paragraph) (in-class and online activities), Task 4 was giving feedback on peer's argumentative essay (Focus on Body Paragraphs) (online activities). Task 5 was giving feedback on peer's argumentative essay (Focus on concluding Paragraph) (online activities). Task 6 was revising and editing the draft based on the feedback from peers and teacher (in-class and online activities). Task 7 was publishing the essay by posting the final product in Edmodo account (online activities), and reviewing the essays (in-class activities).

Cycle II applied the revised instructional procedures of implementing Edmodo in the writing class through the activities of reinforcement of using Edmodo in writing class (in-class and online activities). Task 1 was doing pre writing activity (in-class and online activities). Task 2 was writing a thesis statement (in-class and online activities). Task 3 was organizing the ideas (inclass and online activities). Task 4 was writing first draft (in-class and online activities). Task 5 was taking photo of the results of prewriting activities and outline and uploading into Edmodo account (online activities). Task 6 was post the first draft of argumentative essay in Edmodo account (online activities). Task 7 was giving feedback on peer's argumentative essay (Focus 
on Introductory Paragraph) (in-class and online activities). Task 8 was giving feedback on peer's argumentative essay (Focus on Body Paragraphs) (online activities). Task 9 was giving feedback on peer's argumentative essay (Focus on concluding Paragraph) (online activities). Task 10 was revising and editing the draft based on the feedback from peers and teacher (in-class and online activities). Task 11 was publishing the essay by posting the final product in Edmodo account (online activities) and reviewing (in-class activities). The complete schedule of implementing the action plan is shown in Table 1.

Table 1. Research Time Line (within Lecture Activities)

\begin{tabular}{|c|c|c|c|}
\hline Cycle & Focus/Activities & Weeks/Meeting & Learning Mode \\
\hline \multirow[t]{2}{*}{ Cycle I } & $\begin{array}{l}\text { Training on using } \\
\text { Edmodo in Writing } \\
\text { Class, by: } \\
\text { - } \quad \text { Introducing Edmodo in } \\
\text { writing classroom } \\
\text { - } \quad \text { Showing the procedure } \\
\text { of using Edmodo in } \\
\text { writing class } \\
\text { - } \quad \text { Practicing to upload } \\
\text { file (first draft of their } \\
\text { argumentative essay): } \\
\text { Introductory paragraph } \\
\text { and body paragraph } \\
\text { into Edmodo account } \\
\text { - Practicing on writing } \\
\text { concluding paragraph } \\
\text { and upload it into } \\
\text { Edmodo account } \\
\text { Practicing on giving } \\
\text { feedback on peer's } \\
\text { work in Edmodo } \\
\text { Group (Argumentative } \\
\text { Writing) } \\
\text { Giving feedback } \\
\text { (teacher feedback) on } \\
\text { each student's essay. }\end{array}$ & $\begin{array}{l}\text { Week } 7 \\
\text { (Meeting 1) }\end{array}$ & $\begin{array}{l}\text { In-class and online } \\
\text { activities }\end{array}$ \\
\hline & $\begin{array}{l}\text { Task 1: Do prewriting } \\
\text { activities in Edmodo group } \\
\text { by: }\end{array}$ & $\begin{array}{l}\text { Week } 8 \\
\text { (Meeting 2) }\end{array}$ & $\begin{array}{l}\text { In-class and online } \\
\text { activities }\end{array}$ \\
\hline
\end{tabular}


- grouping students in

the small group via

Edmodo (a group of 3)

randomly, 5 group in

total

- using prewriting

technique (i.e. listing,

clustering, or

freewriting).

- clarifying in mind

what the two sides of

the argument are.

- deciding which side student agrees with.

Task 2: Write the first draft and upload argumentative essay into

In-class and online activities

Edmodo group (small

group).

Task 3: Give comments/feedback/ suggestion on peer's argumentative essay (Focus on Introductory Paragraph).

Task 4: Give comments/feedback/ suggestion on peer's argumentative essay (Focus on Body

Paragraphs).

Task 5: Give Week 9

(Meeting 3) In-class and online activities

Online activities

Online activities comments/feedback/ suggestion on peer's argumentative essay (Focus on Concluding Paragraph).

Task 6: Revise and edit the draft based on the comments/feedback/sugge stion from peers and teacher.

Task 7: Publish the essay by posting the final product of argumentative essay in Edmodo account

\section{Week 10}

(Meeting 4)
In-class and online activities

Online activities 


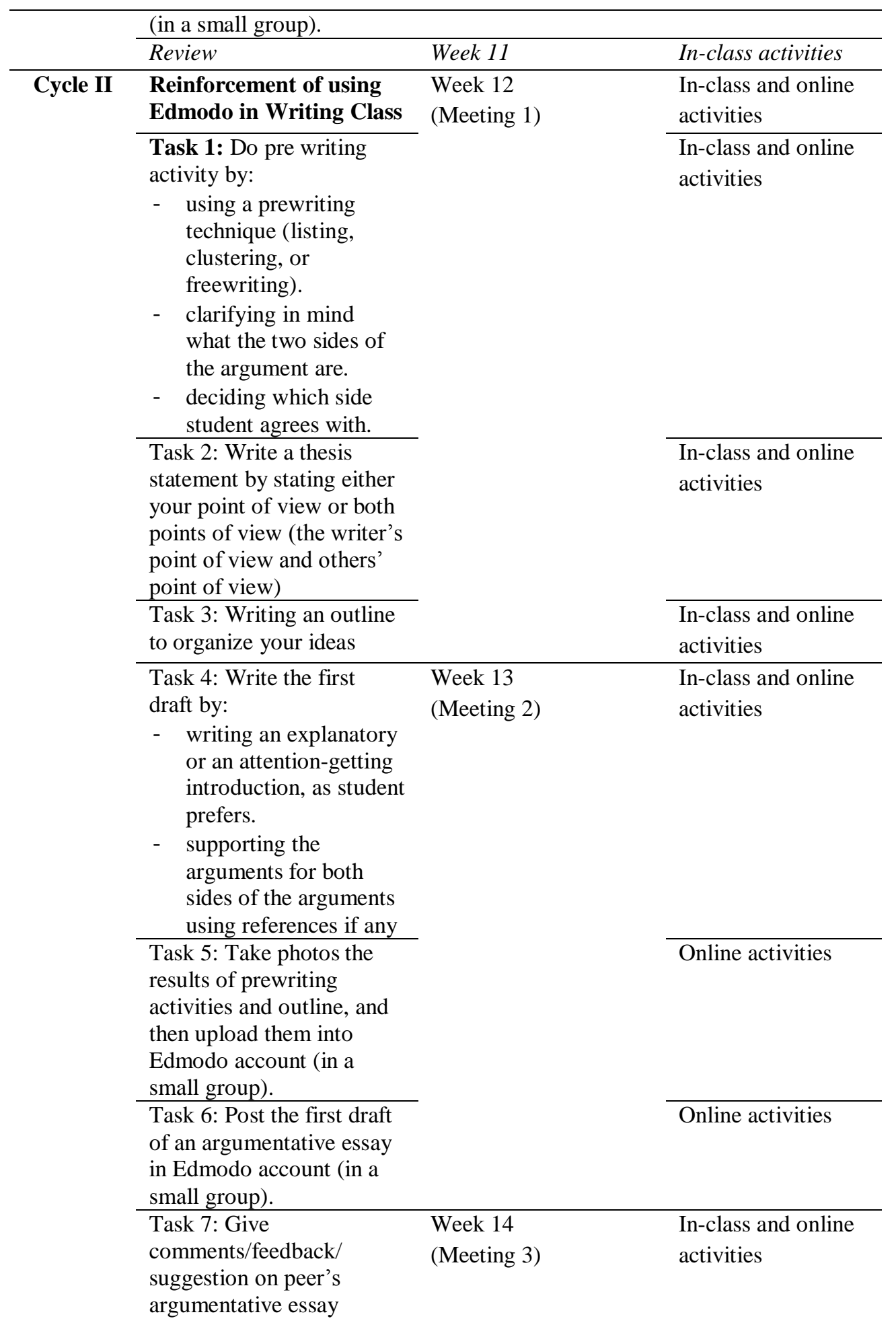


(Focus on Introductory

Paragraph).

Task 8: Give comments/feedback/ suggestion on peer's argumentative essay (Focus on Body

Paragraphs).

Task 9: Give comments/feedback/ suggestion on peer's argumentative essay (Focus on Concluding Paragraph).

Task 10: Revise and edit the draft based on the comments/feedback/sugge stion from peers and teacher.

\section{Task 11: Publish the essay} by posting the final product of argumentative essay in Edmodo account (in a small group).
Online activities

Online activities

$\begin{array}{ll}\text { Week 15 } & \text { In-class and online } \\ \text { (Meeting 4) } & \text { activities }\end{array}$

(Meeting 4)

activities

Online activities

\begin{tabular}{lll}
\hline Review & Week 16 & In-class activities
\end{tabular}

\section{Observing}

The observation was conducted in each meeting in Cycle I and II. It observed the whole aspects of the implementation of the action of teaching writing using Edmodo covering the improvement of the students' writing ability and their involvement during the writing classes of in-class and online activities via the virtual community.

\section{Reflecting}

In this stage, it dealt with the activity to analyze the data. It analyzed the data based on two classifications. The data dealing with the writing achievement in the form of students' writing products in form of argumentative essay were analyzed by utilizing the analytic scoring rubric 
adapted from Oshima \& Houge (2007, p. 316). The writing products were assessed in terms of the three writing components - content, organization, and grammar.

The data dealing with the students' involvement in the writing class during the implementation of Edmodo gathered through observation checklist were analyzed quantitatively based on the number of the scale checked by the observer in the observation checklist. The analysis results, furthermore, were employed to decide whether the class met the predetermined criteria of success. The result of this reflection was then used as the basic consideration to draw a conclusion whether the action stops or needed improving for deciding what next cycle would be done.

\section{RESULTS \& DISCUSSION}

\section{The students' writing achievement}

The students' achievement, in the Cycle I, was not satisfactory yet. The mean score of the students gotten from the writing task was 68.80. This score was greater than those obtained from the writing task in Preliminary Study (64.40). There was an increase in the students' writing achievement. However, the result has not met the first criterion of the succesfull learners. The indicator determined that the students' writing achievement enhances if the mean score of the students is higher than or equal to 70.00 (it is categorized into B or good).

In Cycle I, the majority of the students was struggling to improve their technical skill on how to use Edmodo in the classroom; consequently, they could not yet produce a good argumentative essay. They did not get benefit more from Edmodo as their learning community. Most of them have not yet used Edmodo as a tool in their writing learning appropriately. The students encountered some problems with their tasks during writing activities 
using Edmodo. In doing Task 1, prewriting activities, most of them did not use prewriting technique appropriately and they did not clarify the two sides of the argument stated in the essay and decide which side they agreed as well. In doing Task 2, most of them got difficulties to write first draft and building communication on a small group of Edmodo, particularly in uploading activity. In doing the next tasks of giving comment or feedback on their peers' works, they faced technical problems in responding their peers' works on Edmodo in a small group. Moreover, they did not know how to comment on their peers' works, i.e. on the introduction of the argumentative essay, body paragraphs, and concluding paragraph. The teacher should suggest them to consult to the feedback guidelines. Additionally, most of them took longer time in revising activities. Even though the teacher had signed the useful feedback gotten from their peers in his comment box of each small group, the students sometimes did not pay more attention to the sign "like". Consequently, the students were not able revised properly their essays. For the last task of Cycle I, the majority of the students succeeded to publish their final essays in their own Edmodo account.

After teaching reflection, the teacher evaluated the instructional procedures of the teaching of writing using Edmodo. He revised the teaching procedures to encounter problems found in class activities of the Cycle I.

After doing the action in Cycle II, the students' achievement in writing argumentative increased significantly. The mean score of the students gotten from the writing task was 74.60, higher than the score in Cycle I (68.80). From the findings, there was a slight improvement of the students' writing achievement in producing argumentative essay using Edmodo in Cycle II. Therefore, it met the first criterion of the study success. The 
indicator said that the students' writing achievement enhances if the mean score of the students in the writing task is greater than or equal to 70.00 (it is categorized into B or good).

Inspite of the increasing score, the students continuously made certain types of mistakes in their argumentative essays. The number of the mistakes reduced gradually. Typically, the students doing some mistakes were those who were not active during writing activities using Edmodo. Most of the students' argumentative essays presented better information in terms of the general statement and thesis statement in the introductory paragraph. In addition, each body paragraph had a topic sentence, which was stated fairly, clearly and accurately. Their essays were fairly well organized. They were generally able to develop coherent paragraphs. They had supporting details and proper transitional signals. However, their writings still had some grammatical mistakes. Despite of the errors, their argumentative essays were understandable and readable since they had good content and organization. In addition, in the writing activities during using Edmodo in the virtual community, the students could express or expose their ideas dealing with writing an argumentative essay during conference time in the stages of revising and editing activities.

\section{The students' involvement in writing class using Edmodo}

The students' involvement in writing activities during the class using Edmodo in Cycle I was fair. It is indicated by the average percentage $(69.13 \%)$ of the students, who engage in class activities (11 students of the class were actively involved in the writing activities). This result can be categorized as fail since it did not meet the second criterion of the study success. The indicator requires $70 \%-84 \%$ students of the class or 12-13 students to engage in the class activity in order to reach good category. 
The technical problems on how to use Edmodo encountered.by the students caused the unsatisfactory level of students' involvement in writing activities of cycle I. For instance, they got problems to upload pre-writing activities and outlining argumentative essay into Edmodo account in their own groups and to give feedback in the conference activities during revising and editing stages. Moreover, they could not revise their works which refer to the feedback/comment/suggestion by their peers, and could not produce their argumentative essays well after being given feedback by their peers and the teacher. In addition, they still got difficulties of making coherent paragraphs and essays.

The students' involvement in writing activities during the class using Edmodo in Cycle II was good. The average percentage $(83.13 \%)$ of the students doing the activities (13 students of the class were actively involved in the writing activities) indicates the result. This result was greater than the percentage gained in the previous cycle. This outcome is categorized as succeed since it met the second criterion of the study success.

\section{The instructional procedures of teaching writing using Edmodo}

The research findings in Cycle I and II show how Edmodo as an online tool in EFL writing class can increase the students' ability in producing an argumentative essay. By engaging the students in the writing class during the use of Edmodo as virtual writing community, it seems that they are able to communicate and collaborate with their peers. The communication process was indicated when the students were actively using their English during writing process activities, e.g. in the prewriting, outlining, drafting, revising, editing, and publishing activities using Edmodo as their online writing community during the process of the action cycles. 
The instructional procedures of teaching writing using Edmodo developed by the teacher-researcher and applied in the EFL writing class were adapted from Stroud (2010) and Purnawarman et al. (2016) and based on the material provided in the course of argumentative writing and the students' need. The focus of teaching writing using Edmodo implemented by the teacher-researcher was on the teaching of writing which strongly engaged the students in the process of writing collaboratively. In this activities, the students can revise their works effectively based on peer feedback and teacher feedback. In relation to the writing instruction using Edmodo, it was done by following the steps which were integrated within the lecture activities in argumentative writing class shown in Table 1.

The increase of the students' writing ability after the writing class using

\section{Edmodo}

The utilization of Edmodo as an online tool in EFL writing class with the appropriate instructional procedures can increase the students' ability in writing an argumentative essay. The increase of the students' writing ability can be examined from the indicators: (1) The increase of the students' achievement in writing an argumentative essay, and (2) The students' involvement in the writing class during the use of Edmodo in the process of teaching and learning writing.

The students' achievement in writing argumentative essay is reflected by the increase of the mean score of the students gotten from the writing task in Cycle I and II. The mean score of the students in the writing task of cycle I was 68.80. It increased significantly into 74.60 in Cycle II.

The students' involvement during the writing class using Edmodo shows the improvement the students' participation in the writing activities. Statistical data of cycle I informs that $69.13 \%$ students (11 students of the 
class) involve in the writing activities. The involvement of the students increase significantly in cycle II (83.13\% or 13 students of the class). It means that they actively involved in the writing activities.

\section{CONCLUSION}

The study investigates the utilization of Edmodo as an online tool in Indonesian EFL writing class to increase the students' ability in producing an argumentative essay. The results show that Edmodo as virtual writing community can significantly increase the students' ability in writing argumentative essay, particularly, in the Cycle 2. To reach the goal, the teaching learning process applying Edmodo follows 14 steps. (1) Prepare the teaching materials. (2) Introduce Edmodo in writing classroom. (3) Guide students to get ready to use Edmodo by having a personal account of Edmodo. (4) Give an opportunity to students to get in the Edmodo group by telling them "the group code". (5) Train students to use Edmodo group so that they get involved in writing activities in the group. (6) Group students in the small group via Edmodo (a group of 3). (7) Give students writing tasks through Edmodo accompanied by clear instruction for each task. (8) Provide a guideline and tell students to follow the guideline to access their small group in Edmodo. (9) Ask students to post their first drafts of an argumentative essay on their small groups. (10) Ask students to give comments/feedback/suggestion on their peers' works on the parts of the Introductory Paragraph. (11) Ask students to give comments/feedback/suggestion on their peers' works on the parts of the Body Paragraphs. (12) Ask students to give comments/feedback/suggestion on their peers' works on the parts of the Concluding Paragraph. (13) Ask students to 
revise their drafts of the argumentative essay based on the feedback from the peers (their friends) and their teacher (A useful feedback from their peer is the feedback that was assigned with "like" by Teacher). (14) Ask students to post their final products of an argumentative essay on their Edmodo account (in their own small group).

\section{REFERENCES}

Ali, Z. (2015). A case study of tertiary students' experiences using Edmodo in language learning. International Journal of Language Education and Applied Linguistics (IJLEAL), 2(1), 39-48.

Al-Naibi, I., Al-Jabri, M., \& Al-Kalbani, I. (2018). Promoting students' paragraph writing using Edmodo: An action research. TOJET: The Turkish Online Journal of Educational Technology, 17(1), 130-143.

Anbe, G. (2013). Using Edmodo to incorporate WICOR strategies in the AVID Classroom. Paper presented on TCC Conference (pp. 1-9), retrieved from scholarspace.manoa.hawaii.edu

Cahyono, B.Y. (2010). Teaching English by using internet resources. Malang: State University of Malang.

Çobanoğlu, A. A. (2018). Student teachers' satisfaction for blended learning via Edmodo learning management system. Behaviour \& Information Technology, 37(2), 133-144, DOI: 10.1080/0144929X.2017.1417481

Holland, C., \& Muilenburg, L. Y. (2011). Supporting student collaboration: Edmodo in the classroom. Paper presented on Society for Information Technology \& Teacher Education International Conference, Mar 07, 2011 in Nashville, Tennessee, USA

Kemmis, S. \& McTaggart, R. (1992). The action research planner, $3^{\text {rd }}$ ed. Victoria: Deakin University Press. 
Kistow, B. (2011). Blended learning in a higher education: A study of graduate school of business, Trinidad and Tobago. Carribean Teaching Scholar, 1(2), 115-128.

Kodriyah, L. (2016). Students' perceptions toward the use of Edmodo as an effective tool for learning English. Paper presented at the $63^{\text {rd }}$ TEFLIN International Conference: Creativity and Innovation in Language Materials Development and Language Teaching Methodology in Asia and Beyond, Book 2, University of PGRI Adi Buana Surabaya.

Kongchan, C. (2013). How Edmodo and google docs can change traditional classrooms. Paper presented at the European Conference on Language Learning 2013, Chada Konchan, King Mongkut's University of technology Thonburi, Thailand.

Koshy, V. (2006). Action research for improving practice: A practical guide. London: Paul Chapman Publishing.

Miftah, M. Z. (2015). Enhancing writing skill through writing process approach. Journal on English as a Foreign Language, 5(1), 9-24.

Oshima, A., \& Hogue, A. (2007). Introduction to Academic Writing. $3^{\text {rd }}$ Ed. New York: Longman.

Purnawarman, S., Susilawati, \& Sundayana. (2016). The use of Edmodo in teaching writing in a blended learning setting. Indonesian Journal of Applied Linguistics, 5(2), 242-252.

Salasiah, A. (2016). Edmodo in the class: Students' voice on online learning (A case study at Universitas Muhammadiyah Parepare. Paper presented at the $63^{\text {rd }}$ TEFLIN International Conference: Creativity and Innovation in Language Materials Development and Language 
Teaching Methodology in Asia and Beyond, Book 3, University of PGRI Adi Buana Surabaya.

Stroud, C. (2010). Edmodo: A white paper. Retrieved from Stroudc2@winthrop.edu

Supiani (2012). Improving the students' abilty in writing descriptive texts through collaborative writing technique. Journal on English as a Foreign Language, 2(2), 11-20.

Trust, T. (2015). Deconstructing an online community of practice: Teachers' actions in the Edmodo Math subject community. Journal of Digital Learning in Teacher Education, 31(2), 73-81, DOI: 10.1080/21532974.2015.1011293

Trust, T. (2017). Motivation, empowerment, and innovation: Teachers' beliefs about how participating in the Edmodo Math subject community shapes teaching and learning. Journal of Research on Technology in Education, 49(1-2), 16-30, DOI: 10.1080/15391523.2017.1291317

Ursavaş, Ö. F. \& Reisoglu, I. (2017). The effects of cognitive style on Edmodo users' behaviour: A structural equation modeling-based multi-group analysis. The International Journal of Information and Learning Technology, 34(1), 31-50, DOI: 10.1108/IJILT-06-2016$\underline{0019}$ 